\title{
Pattern-Based Detection of Different Proteins using an Array of Fluorescent Protein Surface Receptors
}

\author{
Laura Baldini, Andrew J. Wilson, Jason Hong and Andrew D. Hamilton \\ Department of Chemistry, P.O. Box 208107, 225 Prospect Street, Yale University, New \\ Haven, Connecticut 06520-8107
}

\section{Supporting Information}

\section{Experimental procedure for the synthesis of the porphyrin library}

\section{Z-Tyrosine $(\mathrm{O} t \mathrm{Bu}) \mathrm{N}-\varepsilon-(t \mathrm{Boc})$ lysine methyl ester}

To a stirred solution containing N- $\alpha$-benzoxycarbanoyl-O- $t$-Butyl-L-tyrosine dicyclohexyl ammonium salt $(1.00 \mathrm{~g}, 1.80 \mathrm{mmol})$, N- $-\mathrm{t}$ butoxycarbanoyl-L-lysine methyl ester hydrochloride $(0.54 \mathrm{~g}, 1.80 \mathrm{mmol})$ and 4-dimethyl amino pyridine $(0.22 \mathrm{~g}$, $1.80 \mathrm{mmol})$ in dichloromethane $(100 \mathrm{~mL})$ at $0^{\circ} \mathrm{C}$ was added EDCI $(0.35 \mathrm{~g}, 1.80 \mathrm{mmol})$. The reaction mixture was stirred for six hours and then washed successively with hydrochloric acid $(1 \mathrm{~N}, 50 \mathrm{~mL})$, saturated sodium bicarbonate solution $(50 \mathrm{~mL})$ and saturated sodium chloride solution $(50 \mathrm{~mL})$. The reaction mixture was then dried over magnesium sulphate, filtered and concentrated to leave on off white foam that was subsequently passed through a short silica gel column $(25 \%$ ethyl acetate in dichloromethane to yield the product as a white foam. Yield $=0.946 \mathrm{~g}, 85 \% ;{ }^{1} \mathrm{H} \mathrm{NMR}$ $\left(400 \mathrm{MHz}, \mathrm{CDCl}_{3}\right) \delta=1.16$ (brm, 2H), 1.31 (s, 9H), 1.41 (s, 9H), 1.59 (brm 2H), 1.74 (brm, 2H), 3.02 (d, 4H, J =6.8 Hz), 3.68 (s, 3H), 4.46 (brm, 2H), 4.86 (brs, 1H), 5.07 (s, 2H), 5.49 (brs, 1H), 6.48 (brs, 1H), 6.86 (d, 2H, $J=8.6 \mathrm{~Hz}), 7.07$ (d, 2H J=8.6 Hz), 7.31 $(\mathrm{m}, 5 \mathrm{H}) ;{ }^{13} \mathrm{C} \mathrm{NMR}\left(100 \mathrm{MHz}, \mathrm{CDCl}_{3}\right) \delta=22.58,28.84,29.21,29.69,32.19,38.15$, $40.49,52.42$, 56.55, 67.46, 78.87, 79.44, 124.78, 128.46, 128.60, 128.86, 128.94,130.21, 131.50, 136.51, 154.69, 156.47, 171.25, 172.57; FAB-MS (mNBA matrix) $\mathrm{m} / \mathrm{z} 614$ $[\mathrm{M}+\mathrm{H}]^{+}$; HRMS $614.3441[\mathrm{M}+\mathrm{H}]^{+}$calcd. for $\mathrm{C}_{33} \mathrm{H}_{47} \mathrm{O}_{8} \mathrm{~N}_{3}(+\mathrm{H})$, found 614.3437 anal. calcd. for $\mathrm{C}_{33} \mathrm{H}_{47} \mathrm{O}_{8} \mathrm{~N}_{3} \mathrm{C}, 64.58 \% ; \mathrm{H}, 7.72 \%$; N, 6.85\%, found: $\mathrm{C}, 64.51 \% ; \mathrm{H}, 7.71 \%$; N, $6.96 \%$.

\section{Z-N- $\varepsilon-(t$ Boc $)$ lysyl-N''- $\varepsilon-(t$ Boc $)-\mathrm{N}$ '2,5-diaminopentane}

To a stirred solution containing $\mathrm{N}-\alpha$-benzoxycarbanoyl- $\mathrm{N}-\varepsilon-(t$ Boc $) l y s i n e ~(1.00 \mathrm{~g}, 2.63$ mmol), $t$-butoxylcarbonyl 2,5-diaminopentane toluensulphonic acid salt $(0.99 \mathrm{~g}, 2.63$ $\mathrm{mmol})$ and 4-dimethyl amino pyridine $(0.32 \mathrm{~g}, 2.63 \mathrm{mmol})$ in dichloromethane $(100 \mathrm{~mL})$ at $0^{\circ} \mathrm{C}$ was added EDCI $(0.50 \mathrm{~g}, 2.63 \mathrm{mmol})$. The reaction mixture was stirred for six hours and then washed successively with hydrochloric acid $(1 \mathrm{~N}, 50 \mathrm{~mL})$, saturated sodium bicarbonate solution $(50 \mathrm{~mL})$ and saturated sodium chloride solution $(50 \mathrm{~mL})$. The reaction mixture was then dried over magnesium sulphate, filtered and concentrated to leave an off white foam that was subsequently passed through a short silica gel column 
(25\% ethyl acetate in dichloromethane to yield the product as a white foam. Yield $=1.21$ g, $82 \% ;{ }^{1} \mathrm{H}$ NMR $\left(400 \mathrm{MHz}\right.$, DMSO-d $\left.{ }_{6}\right) \delta=1.20(\mathrm{~m}, 4 \mathrm{H}), 1.36(\mathrm{~m} 24 \mathrm{H}), 1.50(\mathrm{~m}, 2 \mathrm{H})$, $2.87(\mathrm{~m}, 4 \mathrm{H}), 3.01(\mathrm{~m}, 2 \mathrm{H}), 3.88(\mathrm{dt}, 1 \mathrm{H}, J=8.4,5.3 \mathrm{~Hz}), 5.00(\mathrm{~s}, 2 \mathrm{H}), 6.74(\mathrm{t}, 2 \mathrm{H}, J=$ $5.3 \mathrm{~Hz}), 7.34(\mathrm{~m}, 6 \mathrm{H}), 7.83(\mathrm{t}, 1 \mathrm{H}, J=5.3 \mathrm{~Hz}) ;{ }^{13} \mathrm{C} \mathrm{NMR}\left(100 \mathrm{MHz}, \mathrm{CDCl}_{3}\right) \delta=22.83$, $24.24,28.82,29.42,29.43,29.93,30.02,32.48,39.62,40.18,40.67,55.29,67.40,79.49$, $79.59,128.50,128.60,128.93,136.59,156.51,156.66,156.75,172.74$; FAB-MS (mNBA matrix) $\mathrm{m} / \mathrm{z} 565[\mathrm{M}+\mathrm{H}]^{+}$; HRMS $[\mathrm{M}+\mathrm{H}]^{+} 565.3601$ calcd. for $\mathrm{C}_{29} \mathrm{H}_{48} \mathrm{O}_{7} \mathrm{~N}_{4}(+\mathrm{H})$, found 565.3593; anal. calcd. for CHON () C, 61.68\%; H, 8.57\%; N, 9.92\%, found: C, 61.74\%; $\mathrm{H}, 8.65 \%$;, $9.87 \%$.

\section{Tyrosine $(\mathrm{O} t \mathrm{Bu}) \mathrm{N}-\varepsilon-(t \mathrm{Boc}) \mathrm{lysine}$ methyl ester}

A solution of Z-Tyrosine $(\mathrm{O} t \mathrm{Bu}) \mathrm{N}-\varepsilon-(t \mathrm{Boc})$ lysine methyl ester $(0.426 \mathrm{~g}, 0.69 \mathrm{mmol})$ and $0.05 \mathrm{~g} 10 \%$ palladium on carbon in methanol $(15 \mathrm{~mL})$ was stirred under a hydrogen balloon for six hours. The reaction mixture was then filtered through celite, concentrated and dried in vacuo to leave the product as a white foam. Yield $=0.2633 \mathrm{~g}, 93 \% ;{ }^{1} \mathrm{H}$ NMR $\left(400 \mathrm{MHz}, \mathrm{CDCl}_{3}\right) \delta=1.32(\mathrm{~m}, 12 \mathrm{H}), 1.42(\mathrm{~m}, 11 \mathrm{H}), 1.68(\mathrm{~m}, 1 \mathrm{H}), 1.86(\mathrm{~m}, 1 \mathrm{H})$, $3.04(\mathrm{~m}, 3 \mathrm{H}), 3.20(\mathrm{~m}, 1 \mathrm{H}), 3.69(\mathrm{~s}, 3 \mathrm{H}), 4.01(\mathrm{~m}, 0.5 \mathrm{H}), 4.49(\mathrm{~m}, 1 \mathrm{H}), 4.87(\mathrm{~m}, 0.5 \mathrm{H})$, $6.91(\mathrm{~d}, 2 \mathrm{H}, J=8.0 \mathrm{~Hz}), 7.18(\mathrm{~d}, 2 \mathrm{H}, J=7.6 \mathrm{~Hz}), 7.76(\mathrm{~d}, 1 \mathrm{H}, J=7.6 \mathrm{~Hz}) ;{ }^{13} \mathrm{C} \mathrm{NMR}$ $\left(100 \mathrm{MHz}, \mathrm{CDCl}_{3}\right) \delta=22.92,28.84,29.21,29.82,32.08,38.94,40.68,52.44,52.73$, $55.89,78.97,79.45,124.85,128.95,130.51,131.27,154.79,156.56,172.80 ;$ EI-MS $\mathrm{m} / \mathrm{z}$ $480[\mathrm{M}+\mathrm{H}]^{+}$; HRMS $[\mathrm{M}+\mathrm{H}]^{+}$calcd. for $\mathrm{CHON}$ (), found; anal. calcd. for $\mathrm{C}_{25} \mathrm{H}_{41} \mathrm{O}_{6} \mathrm{~N}_{3} \mathrm{C}$, $62.61 \% ; \mathrm{H}, 8.62 \% ; \mathrm{N}, 8.76 \%$, found: C, $59.07 \%$;, $8.52 \%$; N, $8.11 \%$.

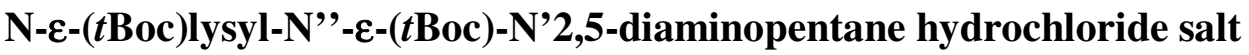

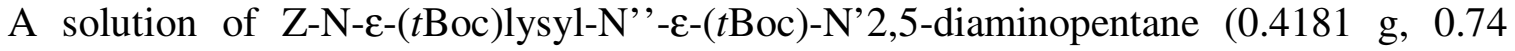
mmol) and $0.05 \mathrm{~g} 10 \%$ palladium on carbon in methanol $(15 \mathrm{~mL})$ was stirred under a hydrogen balloon for six hours. The reaction mixture was then filtered through celite, concentrated and dried in vacuo to leave an oil. This was taken up in dichloromethane (5 $\mathrm{mL}$ ), hydrochloric acid was added $(0.74 \mathrm{~mL} 1 \mathrm{~N}$ solution in ether) and the reaction mixture was concentrated then dried thoroughly to leave the product as a clear amorphous solid. Yield $=0.340 \mathrm{~g}, 98 \% ;{ }^{1} \mathrm{H}$ NMR $\left(400 \mathrm{MHz}, \mathrm{CDCl}_{3}\right) \delta=1.24(\mathrm{~m}, 4 \mathrm{H})$, $1.36(\mathrm{~s}, 20 \mathrm{H}), 1.49(\mathrm{~m}, 4 \mathrm{H}), 1.68(\mathrm{~m}, 2 \mathrm{H}), 2.88(\mathrm{~m}, 4 \mathrm{H}), 3.04(\mathrm{dt}, 1 \mathrm{H}, J=7.0,5.8 \mathrm{~Hz})$, $3.11(\mathrm{dt}, 1 \mathrm{H}, J=7.0,6.0 \mathrm{~Hz}), 3.67(\mathrm{~m}, 1 \mathrm{H}), 6.76(\mathrm{~m}, 2 \mathrm{H}), 8.21(\mathrm{brs}, 3 \mathrm{H}), 8.52(\mathrm{t}, 1 \mathrm{H}, J=$ $5.3 \mathrm{~Hz}) ;{ }^{13} \mathrm{C} \mathrm{NMR}\left(100 \mathrm{MHz}, \mathrm{CDCl}_{3}\right) \delta=; \mathrm{EI} \mathrm{m} / z 431[\mathrm{M}+\mathrm{H}]^{+}$; HRMS $431.3233[\mathrm{M}+\mathrm{H}]^{+}$ calcd. for $\mathrm{C}_{21} \mathrm{H}_{42} \mathrm{O}_{5} \mathrm{~N}_{4}(+\mathrm{H})$, found 431.3230 ; anal. calcd. for $\mathrm{C}_{21} \mathrm{H}_{42} \mathrm{O}_{5} \mathrm{~N}_{4} \mathrm{C}, 54.00 \%$; $\mathrm{H}$, 9,28\%; N, $12.00 \%$, found: C, $52.02 \% ; \mathrm{H}, 9.31 \% ; \mathrm{N}, 11.29 \%$.

\section{(O-t-Butyl)Tyrosylaspartic acid di-t-butyl ester}

To a stirred solution containing $\mathrm{N}-\alpha$-flourenyloxycarbanoyl-O-t-Butyl-L-tyrosine ( $2.08 \mathrm{~g}$, $4.53 \mathrm{mmol})$, aspartic acid di-t-butyl ester hydorchloride (1.00 g, $4.08 \mathrm{mmol})$ and 4dimethyl amino pyridine $(0.50 \mathrm{~g}, 4.09 \mathrm{mmol})$ in dichloromethane $(100 \mathrm{~mL})$ at $0^{\circ} \mathrm{C}$ was added EDCI $(0.87 \mathrm{~g}, 4.54 \mathrm{mmol})$. The reaction mixture was stirred overnight and then washed successively with hydrochloric acid $(1 \mathrm{~N}, 50 \mathrm{~mL})$, saturated sodium bicarbonate solution $(50 \mathrm{~mL})$ and saturated sodium chloride solution $(50 \mathrm{~mL})$. The reaction mixture was dried over magnesium sulphate, filtered and concentrated under reduced pressure to 
leave an off-white foam that was stirred in $10 \%$ diethylamine in acetonitrile $(100 \mathrm{~mL})$ until the spot attributable to the protected dipeptide had disappeared as evidenced by TLC (25\% ethyl acetate in dichloromethane). The reaction mixture was then concentrated and purified by column chromatography (25\% ethyl acetate in dichloromethane followed by $10 \%$ methanol in dichloromethane) to yield the product as a yellow oil that solidified over several days. Yield: $1.29 \mathrm{~g}, 68 \%$; ${ }^{1} \mathrm{H}$ NMR $\left(400 \mathrm{MHz}, \mathrm{CDCl}_{3}\right) \delta=1.33(\mathrm{~s}, 3 \mathrm{H})$, $1.44(\mathrm{~s}, 3 \mathrm{H}), 1.46(\mathrm{~s}, 3 \mathrm{H}), 2.57(\mathrm{dd}, 1 \mathrm{H}, J=13.6,9.8 \mathrm{~Hz}), 2.68(\mathrm{dd}, 1 \mathrm{H}, J=16.7,4.5 \mathrm{~Hz})$, $2.88(\mathrm{dd}, 1 \mathrm{H}, J=16.9,4.5 \mathrm{~Hz}), 3.21(\mathrm{dd}, 1 \mathrm{H}, J=13.6,3.5 \mathrm{~Hz}), 3.62(\mathrm{dd}, 1 \mathrm{H}, J=9.8,3.5$ $\mathrm{Hz}), 4.69(\mathrm{dt}, 1 \mathrm{H}, J=8.6,4.5 \mathrm{~Hz}), 6.92(\mathrm{~d}, 2 \mathrm{H}, J=8.6 \mathrm{~Hz}), 7.10(\mathrm{~d}, 2 \mathrm{H}, J=7.1 \mathrm{~Hz}) ;{ }^{13} \mathrm{C}$ NMR $\left(100 \mathrm{MHz}, \mathrm{CDCl}_{3}\right) \delta=27.87,28.00,28.89,37.64,49.04,56.08,77.93,80.91$, 81.39, 123.74, 130.16, 133.28, 153.72, 169.65, 165.97, 174.48; FAB-MS (mNBA matrix) $m / z 465[\mathrm{M}+\mathrm{H}]^{+}$; HRMS $465.2964[\mathrm{M}+\mathrm{H}]^{+}$calcd. for $\mathrm{C}_{25} \mathrm{H}_{40} \mathrm{O}_{6} \mathrm{~N}_{2}(+\mathrm{H})$ (465), found 465.2965; anal. calcd. for $\mathrm{C}_{25} \mathrm{H}_{40} \mathrm{O}_{6} \mathrm{~N}_{2} \mathrm{C}, 64.13 \% ; \mathrm{H}, 8.68 \%$; N, $6.03 \%$, found: $\mathrm{C}$, $65.37 \% ; \mathrm{H}, 8.72 \% ; \mathrm{N}, 5.84 \%$.

\section{General Mixed Condensation Synthesis of Porphyrins}

To a stirred solution containing meso-tetra-carboxyphenyl porphine $(0.05 \mathrm{~g}, 0.063$ $\mathrm{mmol})$, peptide $1(0.190 \mathrm{mmol})$, peptide $2(0.190 \mathrm{mmol})$ and diisopropylethylamine $(0.132 \mathrm{~mL}, 0.760 \mathrm{mmol})$ in anhydrous dimethylformamide $(15 \mathrm{~mL})$ under an atmosphere of nitrogen at room temperature was added PyBOP reagent $(0.197 \mathrm{~g}, 0.380 \mathrm{mmol})$. The reaction mixture was allowed to stir overnight and then methylisocyanate polystyrene resin $(0.340 \mathrm{~g}, 0.063 \mathrm{mmol}, 200-400 \mathrm{mesh} 1.8 \mathrm{mmol} / \mathrm{g})$ was added and stirring continued for a further three hours. The reaction mixture was filtered and the solid support washed with a dichloromethane $(3 \times 5 \mathrm{~mL})$. The reaction mixture was then poured into water $(70$ $\mathrm{mL}$ ) and extracted with ethyl acetate $(3 \times 30 \mathrm{~mL})$. The combined organic extracts were washed with water $(5 \times 25 \mathrm{~mL})$, hydrochloric acid $(25 \mathrm{~mL})$, saturated sodium bicarbonate solution $(25 \mathrm{~mL})$ and saturated sodium chloride solution $(25 \mathrm{~mL})$, then dried over magnesium sulphate, filtered and concentrated to leave a mixture of protected porphyrins. The prophrins were then separated using silica gel preparative TLC plates, at which point an NMR was recorded to identify the porphyrin and assess its purity. Finally, individual porphyrin products were stirred in a solution comprising $2.5 \%$ triethylsilane, $2.5 \%$ water, 47.5\% trifluoroacetic acid and $47.5 \%$ dichloromethane over a period of four-six hours, then concentrated, dissolved in water and lyophilized to yield the deprotected porphyrins as powders. The porphyrins were characterized by MALDI-TOF mass spectrometry and purity confirmed with reverse phase HPLC. The ${ }^{1} \mathrm{H}$ NMR spectrum of a number of the deprotected porphyrins was also recorded to confirm the success of the deprotection.

Porphyrin A: MALDI-TOF-MS m/e $1902[\mathrm{M}+\mathrm{H}]^{+}$calcd for $\mathrm{C}_{101} \mathrm{H}_{88} \mathrm{~N}_{12} \mathrm{O}_{27}(+\mathrm{H})$, found 1903.

Porphyrin B: MALDI-TOF-MS m/e $1837[\mathrm{M}+\mathrm{H}]^{+}$calcd for $\mathrm{C}_{98} \mathrm{H}_{96} \mathrm{~N}_{14} \mathrm{O}_{23}(+\mathrm{H})$, found 1837.

Porphyrin C: MALDI-TOF-MS m/e $1630[\mathrm{M}+\mathrm{H}]^{+}$calcd for $\mathrm{C}_{88} \mathrm{H}_{86} \mathrm{~N}_{12} \mathrm{O}_{20}(+\mathrm{H})$, found 1631.

Porphyrin D: MALDI-TOF-MS m/e $1430[\mathrm{M}+\mathrm{H}]^{+}$calcd for $\mathrm{C}_{80} \mathrm{H}_{96} \mathrm{~N}_{14} \mathrm{O}_{11}(+\mathrm{H})$, found 1430.

Porphyrin E: MALDI-TOF-MS m/e $1826[\mathrm{M}+\mathrm{H}]^{+}$calcd for $\mathrm{C}_{102} \mathrm{H}_{124} \mathrm{~N}_{18} \mathrm{O}_{14}(+\mathrm{H})$, found 1826. 
Porphyrin F: MALDI-TOF-MS m/e $1250[\mathrm{M}+\mathrm{H}]^{+}$calcd for $\mathrm{C}_{64} \mathrm{H}_{50} \mathrm{~N}_{8} \mathrm{O}_{20}(+\mathrm{H})$, found 1250.

Porphyrin G: MALDI-TOF-MS m/e $1958[\mathrm{M}+\mathrm{H}]^{+}$calcd for $\mathrm{C}_{106} \mathrm{H}_{104} \mathrm{~N}_{14} \mathrm{O}_{24}(+\mathrm{H})$, found 1960.

Porphyrin H: MALDI-TOF-MS m/e $1500[\mathrm{M}+\mathrm{H}]^{+}$calcd for $\mathrm{C}_{84} \mathrm{H}_{106} \mathrm{~N}_{16} \mathrm{O}_{10}(+\mathrm{H})$, found 1500 .

\section{Fluorescent array and fluorescence titrations}

\section{General details}

Stock solutions of porphyrins were prepared to a concentration of $1 \mathrm{mM}$ in DMSO and then diluted to the desired concentration in $5 \mathrm{mM}$ phosphate buffer, $\mathrm{pH} 7.4$, containing $0.05 \%$ of Tween 20 . Horse heart cytochrome $c$, clostridium pasteurianum ferredoxin, pseudomonas aeruginosa cytochrome $c 551$, horse heart myoglobin and bovine hemoglobin were purchased from Sigma and used without further purification unless otherwise stated. Stock solutions of proteins were prepared in $5 \mathrm{mM}$ phosphate buffer and the $\mathrm{pH}$ adjusted to 7.4 via addition of $1 \mathrm{~N}$ sodium hydroxide or $1 \mathrm{~N} \mathrm{HCl}$. Ferredoxin and cytochrome $c 551$ were subjected to ultrafiltration ( $5 \mathrm{kDa}$ molecular cutoff), then dissolved in $5 \mathrm{mM}$ phosphate and subjected to ultrafiltration two more times to remove undesired salts. The concentration of proteins was determined from the absorbance at the following wavelengths: cytochrome $c \varepsilon(550 \mathrm{~nm})=29500$ (after reduction to $\mathrm{Fe}$ (II) with sodium dithionite); ferredoxin $\varepsilon(390 \mathrm{~nm})=30000$ in phosphate, $\mathrm{pH} 7.4$; cytochrome $c 551$ $\varepsilon(551 \mathrm{~nm})=31400$ (after reduction to Fe(II) with sodium dithionite); myoglobin $\varepsilon(422$ $\mathrm{nm})=116000\left(\right.$ as ferric cyanide derivative $\left.{ }^{1}\right)$; hemoglobin $\varepsilon(540 \mathrm{~nm})=12500$ (as ferric cyanide derivative ${ }^{1}$ ). UV-vis spectra were measured using an Agilent A453 spectrometer or a Molecular Devices Spectra Max 250 plate reader spectrometer. Fluorescence spectra were measured on a Hitachi F-4500 instrument. The excitation wavelength was taken as the maximum of the soret band in the UV spectrum. The picture of the solution array was taken with a Fujix digital camera HC-300Z while the 96-well quartz plate was sitting on a VWR benchtop ultraviolet transilluminator $(302 \mathrm{~nm}$ ). During all the titrations the protein solution contained a concentration of porphyrin equivalent to that in the porphyrin solution, so that the total concentration of the chromophore was kept constant.

\footnotetext{
${ }^{1}$ The protein stock solution is titrated into an aqueous solution of $\mathrm{NaHCO}_{3}(0.1 \%), \mathrm{K}_{3}\left[\mathrm{Fe}(\mathrm{CN})_{6}\right](0.02 \%)$ and $\mathrm{KCN}(0.005 \%)$ in the spectophotometer cuvette.
} 


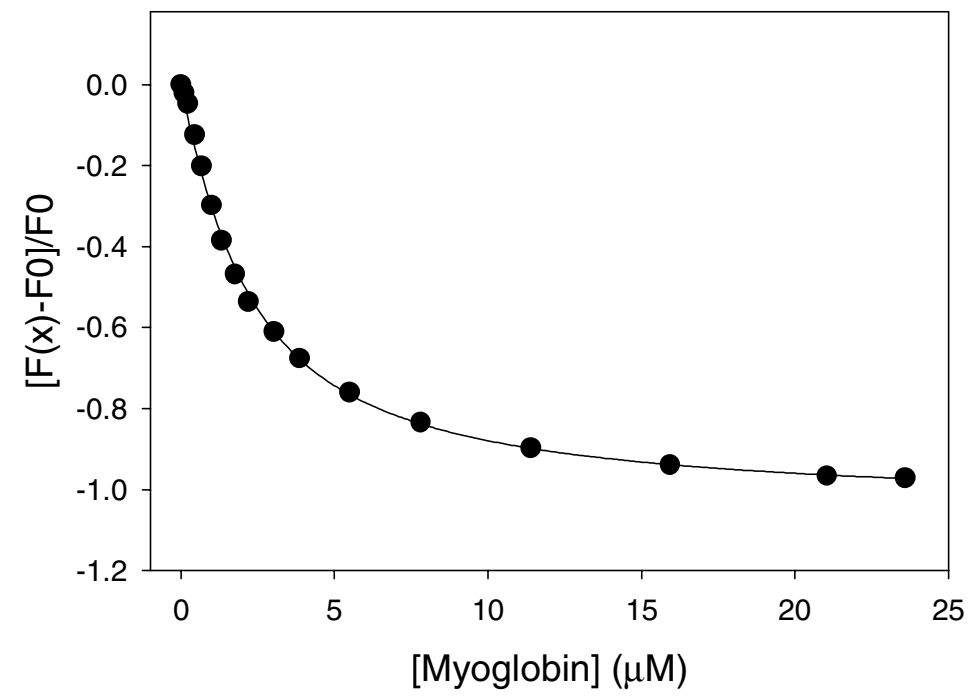

Porphyrin A. Titrations were carried out at $1 \mu \mathrm{M}$ constant porphyrin concentration in 5 mM sodium phosphate buffer containing $0.05 \%$ Tween 20 and $0.1 \%$ DMSO, at 298K.

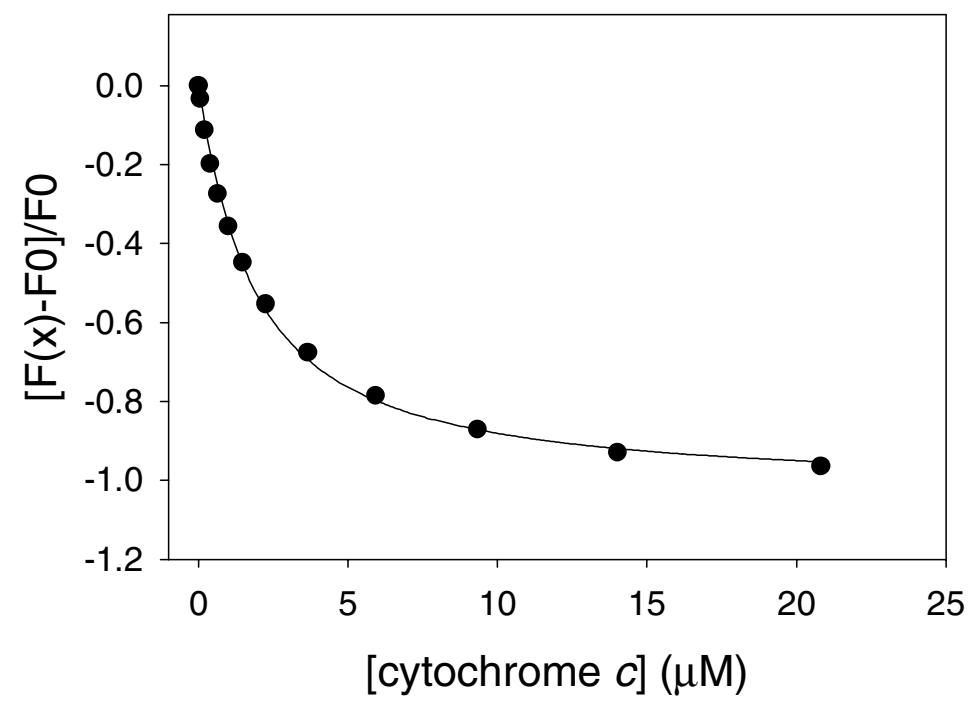

Porphyrin B. Titrations were carried out at $0.5 \mu \mathrm{M}$ constant porphyrin concentration in 5 $\mathrm{mM}$ sodium phosphate buffer containing $0.05 \%$ Tween 20 and $0.05 \%$ DMSO, at $298 \mathrm{~K}$. 


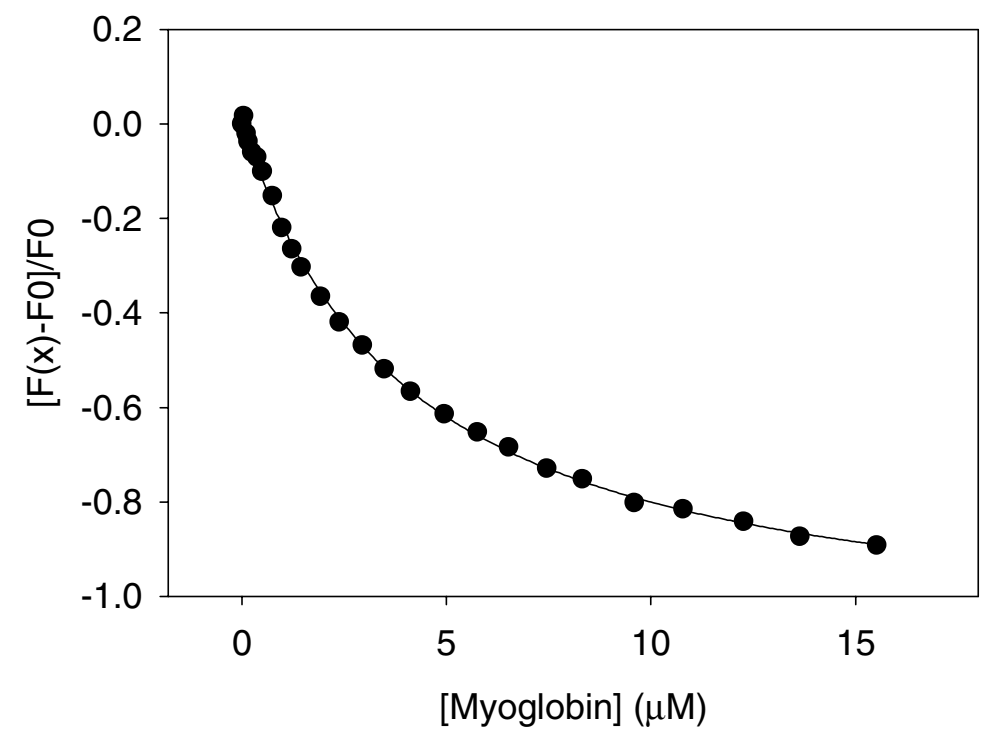

Porphyrin E. Titrations were carried out at $0.5 \mu \mathrm{M}$ constant porphyrin concentration in 5 $\mathrm{mM}$ sodium phosphate buffer containing $0.05 \%$ Tween 20 and $0.05 \%$ DMSO, at $298 \mathrm{~K}$.

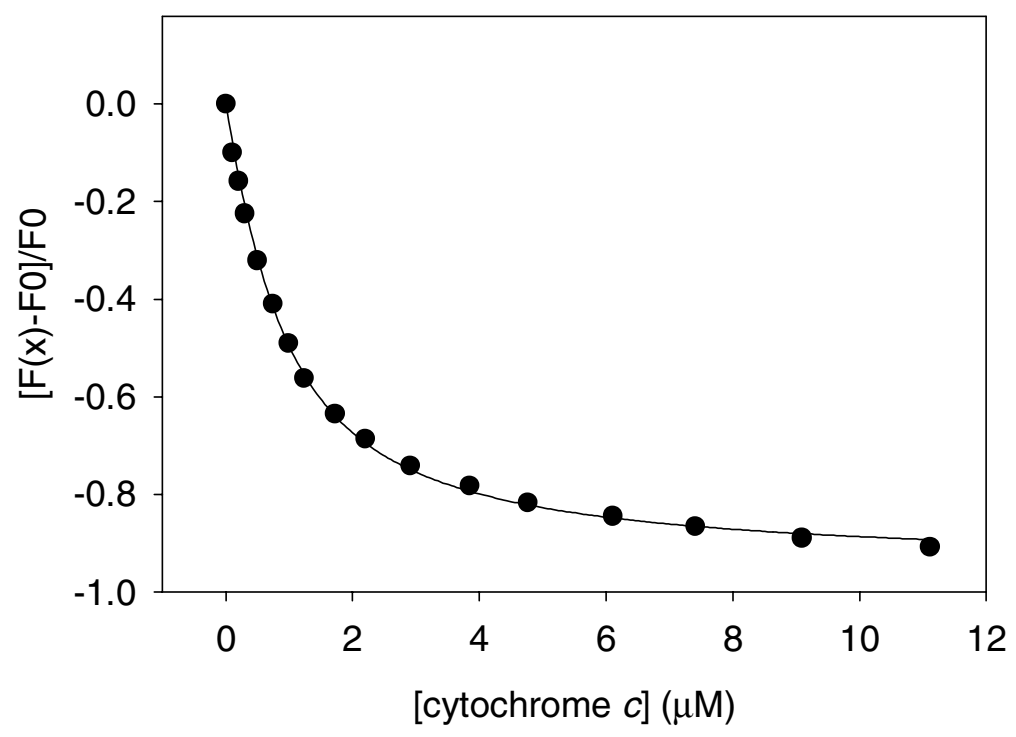

Porphyrin F. Titrations were carried out at $0.5 \mu \mathrm{M}$ constant porphyrin concentration in 5 $\mathrm{mM}$ sodium phosphate buffer containing 0.05\% Tween 20 and $0.05 \%$ DMSO, at $298 \mathrm{~K}$. 


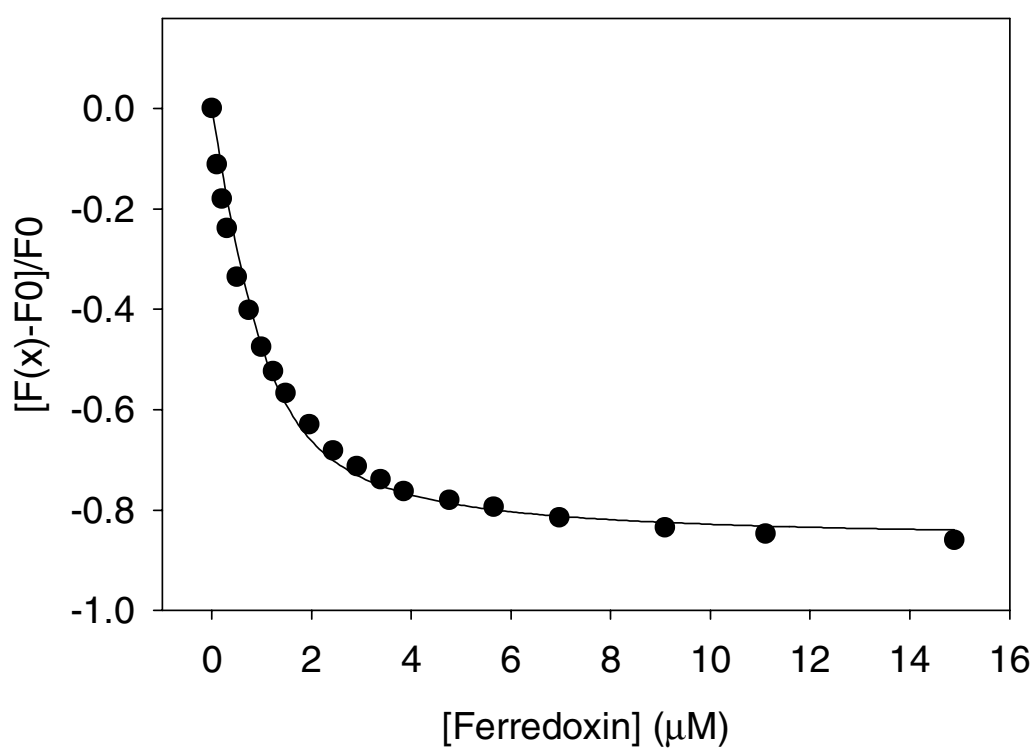

Porphyrin H. Titrations were carried out at $1 \mu \mathrm{M}$ constant porphyrin concentration in 5 $\mathrm{mM}$ sodium phosphate buffer containing $0.05 \%$ Tween 20 and $0.1 \%$ DMSO, at $298 \mathrm{~K}$.

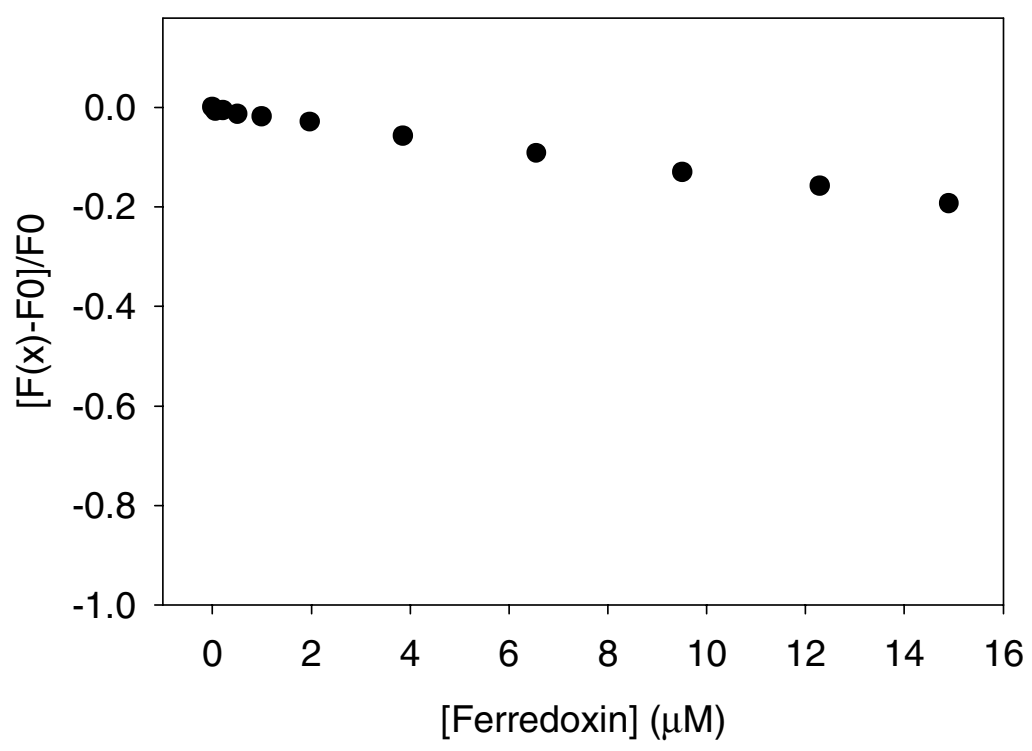

Porphyrin A. Titrations were carried out at $1 \mu \mathrm{M}$ constant porphyrin concentration in 5 $\mathrm{mM}$ sodium phosphate buffer containing $0.05 \%$ Tween 20 and $0.1 \%$ DMSO, at $298 \mathrm{~K}$. 